\title{
ATYPICAL MODES OF EMPLOYMENT IN EAST GERMAN SMES - PATTERNS OF UTILIZATION, INTENTIONS AND PROBLEMS
}

This article at hand presents the results of an explorative empirical investigation in East German SMEs. The focus of the article is on the usage of different modes of atypical employment by these firms. Additionally, the purposes as well as the difficulties accompanying this practice are highlighted. Moreover, the results of the survey will be interpreted in different ways.

Large firms have, for some years used atypical forms of employment, such as part-time work and temporary employment. However, in Germany nowadays small and medium sized firms (SMEs) are also using such forms. Atypical employment seems to be an appropriate means to deal with the situation of SMEs, as these firms are under increased pressure to cut down costs and to become more flexible. Compared to West Germany, East German SMEs use atypical employment more intensively (Schäfer, 2000: 46.p.; Düll Ellguth, 1999: 279.p.). This is often motivated by their economic situation, which is defined as precarious.

The following chapter highlights relevant findings from the German literature on atypical employment in SMEs. Subsequently, I outline the two research questions of the study. Following the description of the sample and the methodology, the results of the study will be presented. The following discussion highlights possible factors influencing the results as well as its implications with regards to the management and the employees. The concluding remarks will summarize the main findings and will outline further research directions.

\section{Atypical employment in German SMEs}

In the Federal Republic of Germany the use of atypical employment by larger firms is slightly decreasing. In contrast, the usage by SMEs is increasing (Rudolph -
Schröder, 1997: 111.p.; Düll - Ellguth, 1999: 279.p.; Krömmelbein, 2000: 140.p.). Therefore, it is argued that typical unlimited employment in German medium-sized businesses tends to disappear (Bellmann et al., 2004: 40.p.).

On the one hand, the reason for the increased use of atypical employment by SMEs is seen in the fact, that such employment could particularly be found in newly founded and young firms that are small and medium in nature (Hoffmann - Walwei, 1998: 419.p.; Schäfer, 2000:46.p.). This point is also highlighted in the international discussion by Melissa Cardon (2003). She understands atypical employment as the possibility to bolster the growth of newly founded SMEs. According to Cardon (2003: 363.p.), different forms of atypical employment seem to be useful in different developmental stages of the firm (start-up, expansion, maturity, and diversification).

On the other hand, like with large firms, positive performance outcomes are expected, in particular increased numerical flexibility and cost savings (Brewster et al., 1994: 170.p.; Nienhüser - Baumhus, 2002: 75.p.; Corral - Isusi, 2003: 2.p.). ${ }^{1}$

An additional reason for the increased use of atypical employment by SMEs could be institutional isomorphism (Mayne et al., 2000: 72.p.). Small and medium sized firms imitate the apparently successful strategies of large enterprises to cope with increased 
competition. In Germany such behaviour is fostered by the increasing amount of academic and non-academic literature on atypical employment (Martin Nienhüser, 2002: 1.p.) and by the fact that this form of employment is accepted within the society (Grimm, 2004).

According to some statistics, firms in EastGermany, which are predominantly small and medium-sized, are using atypical employment on a higher level than firms in the western part of the country (w/o author, 2000: 4.p.; Schäfer, 2000: 46.p.; Düll - Ellguth, 1999: 279.p.). However, according to other sources, diverse developments could be observed in different modes of atypical development (Bellmann et al., 2004: 40.p.; Hoffmann - Walwei, 1998: 418.p.; IAB-Betriebspanel Ost, 2003: 28.ff.). The increased usage of atypical employment in East-Germany is explained with the higher economic uncertainness of the firms and prevalent governmental provisions of work for the unemployed (w/o author, 2000: 5.p.; Schäfer, 2000: 46.p.; Vogel, 1999: 16.p.). Moreover, it is argued that firms in the Eastern part of Germany are precursors of future production and employment models, as they still face the consequences of the radical transformation processes (Brinkmann, 1996, 2003).

Altogether, the German research on atypical employment in SMEs is often reduced to statistical analysis of its degree of use. However, the aims of the usage of atypical modes of employment and whether these can be achieved are so far no topic of discussion. It is often implicitly assumed that SMEs use atypical employment for the purposes of increased flexibility and reduced labour costs. Nevertheless, possible problems that are typical of SMEs are neglected. Of course, one can assume that these might be similar to those of large firms, e.g. learning and adaptation problems, reduced quality or lower degrees of trust (Brewster et al., 1994: 171.p.; Cardon, 2003: 360.p.; Pearce, 1993: 1090.p.). Nonetheless empirical data on specific difficulties of SMEs is not available.

Based on the literature, it could be concluded that there is a lack of research on atypical employment in SMEs. In particular, the following research questions are not addressed so far: Why is atypical employment used by SMEs? Do the firms favour certain forms? If so, why? What are specific difficulties encountered by the management and the employees? It could be assumed, for instance that SMEs have more difficulties with temporary employment agencies than large firms, as they use temporary workers less often and on low scale. Therefore SMEs have less power over these agencies. Moreover, it could be expected that SMEs face more internal difficulties with atypical workers, as they usually need motivated generalists. Additionally, the intense social relationships among the employees could make atypical workers to oppressed outsiders, on the one hand. On the other hand, the usage of atypical workers could lead to tensions between the core employees and the firm's management.

\section{Research Questions}

The presented study addresses a set of the research questions mentioned above. Based on an empirical investigation among East-German SMEs, the various forms of utilisation of atypical employment as well as its aims and the difficulties accompanying this practice will be highlighted. On the one hand, the focus on East-German enterprises is motivated by the location of the home university of the author. On the other hand, East-German firms are usually small and medium sized and it is expected that they use atypical modes of employment because of their precarious economical situation.

The aim of the study is to develop a picture of atypical employment in East-German medium-sized businesses. Thereby two points are focused on:

- Firstly, the intentions of the firm's management to use atypical employment will be addressed. It is assumed that such employment is used predominantly because of economic reasons. This assumption is deduced from the literature, where cost savings and flexibility are the main arguments for the use of atypical employment. However, the questionnaire also comprised social aims, such as to increase employee motivation and satisfaction.

- Secondly, the study focuses on difficulties the enterprises face, when they use atypical employment. To get a comprehensive picture the questionnaire comprises nearly all difficulties known from the literature. Moreover, the responses regarding actual problems with atypical employment made by the firm's management are contrasted with responses from worker representatives. It is assumed that worker representatives perceive different problems than the management does. 
In addition to the predefined answers, the questionnaire provides room for own comments by the respondents. Thus, they have the opportunity to make additional statements.

\section{Sample and Methodology}

The explorative cross-section study is based on a two-page questionnaire that was sent to the management of 736 SMEs (between 20-1000 employees) in Saxony and the neighbouring federal states of Thuringia, Brandenburg, and Saxony-Anhalt. The addresses were generated from the data base „ABC of the German Economy”.

288 questionnaires were returned (rate of return $39.1 \%$ ). All of them were included in the analysis. The better part of the questionnaires came from firms in Saxony (168), the remainder from Thuringia (41), Brandenburg (8), and Saxony-Anhalt (34). Thus, the number of the returned questionnaires is Saxonycentred. The number of employees varied between 5 and 900 .

The allocation of the firms on different branches is shown in table 1 .

Table 1

Branch allocation

\begin{tabular}{|l|c|}
\hline Branch & Percentage \\
\hline iron and steel industry, non-ferrous metals & 15,3 \\
\hline machine construction, apparatus engineering & 12,8 \\
\hline construction, sub-construction work & 9,7 \\
\hline chemical industry & 8,7 \\
\hline leather & 6,3 \\
\hline electrical engineering & 4,9 \\
\hline food and luxury food industry & 4,5 \\
\hline stones, earths, glass, ceramic, porcelain & 3,5 \\
\hline wood, furniture & 3,5 \\
\hline plastics & 3,5 \\
\hline services & 3,5 \\
\hline research and development & 2,8 \\
\hline automotive industry & 2,8 \\
\hline textile industry & 1,4 \\
\hline precision mechanics, optic, watches & 0,7 \\
\hline media industry & 0,7 \\
\hline tool making, mould making, model making & 0,3 \\
\hline toys & 0,3 \\
\hline not specified & 14,9 \\
\hline
\end{tabular}

In addition to the management questionnaires we sent questionnaires to worker representatives in Saxony. The 40 returned questionnaires were included in the analysis; especially the responses of the worker representatives on difficulties with atypical employment in the companies.

The study focused on four different forms of atypical employment:

- temporary employment (employees from a temporary employment agency, based on specific regulations in Germany law)

- part-time employment (employees with temporarily or permanently reduced working hours)

- short-time employment (in Germany so called „Mini-Jobs” with up to 400 Euro remuneration)

- telecommuting (employees, who work at home using computers and who communicate with the firm via phone, fax machine, or the internet)

It is assumed that these forms are used most frequently by the firms and therefore are well known to them. However, the respondents had the opportunity to mention the use of different forms of atypical employment in the questionnaire.

\section{Results}

\section{Ways of utilisation}

Most of the East-German SMEs use atypical employment ( $87.5 \%) .12 .6 \%$ of the firms do not use this form of employment, because they need specific employee qualifications or they believe that the disadvantages of atypical employment prevail.

Figure 1 shows, how the different forms of atypical employment are used by the firms.

Figure 1:

Firms utilisation of different forms of atypical employment

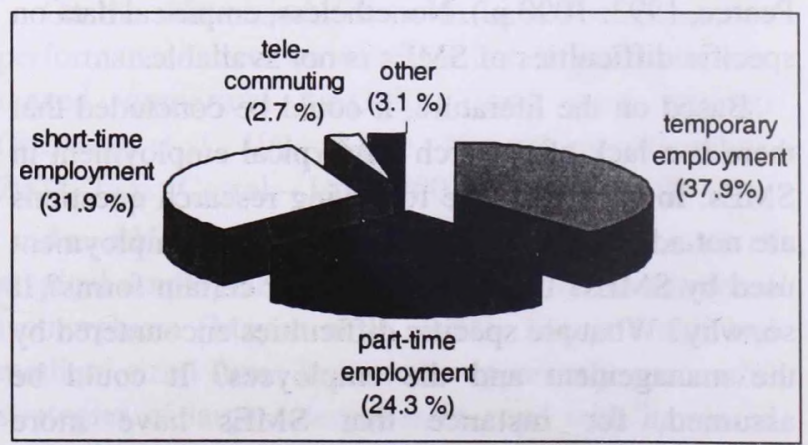


The usage of employees from a temporary employment agency is the dominant form of atypical employment in East-German small and medium sized businesses. Part-time work and short-time employment constitute the middle field. There is virtually no use of telecommuting by the firms. Other forms of atypical employment, mentioned by the firms, were temporary jobs by pupils and students, student trainees, and home workers.

The proportion of atypical employment of the total number of employees of the firms is low (mostly less than $10 \%$ ). Consequently, the results of this study do not support the argument held by some German authors, that typical unlimited employment is substituted by atypical employment. In contrast, German small and medium sized companies tend to use different forms of atypical employment as supplement to their regular staff. The firms maintain stable core staffs, which are expanded with flexible forms of employment, when necessary.

Figure 2 outlines the fields of utilisation of atypical employment.

Figure 2:

Fields of utilisation of atypical employment

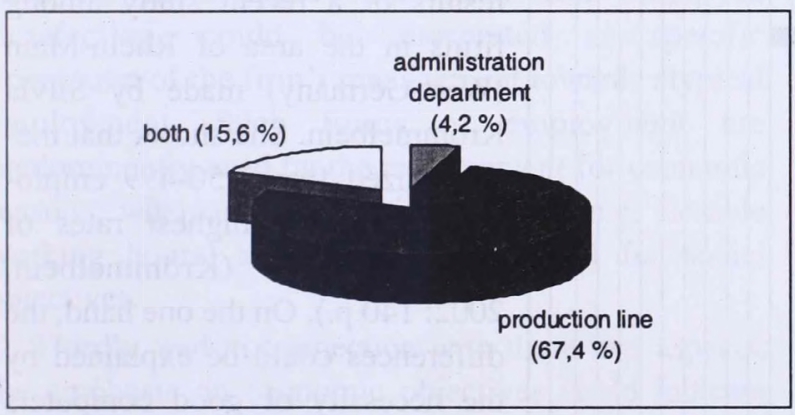

Atypical employment is predominantly used in production lines $(67.4 \%)$, normally as temporary work. Only a few firms use atypical employment (normally short-time employment) in the administration department $(4.2 \%)$. To some extent, atypical employees are used in production lines and administrative department (15.6\%).

\section{Intentions of utilisation}

The question as to whether atypical employment is used to achieve certain objectives, is affirmed by 76.6 $\%$ of the companies ( $23.4 \%$ deny). ${ }^{2}$ In Figure 3 the different objectives are presented.

The results show that economic objectives dominate, particularly increased productivity (by cost savings) and increased flexibility. The same results are found when the different forms of atypical employment are analysed separately.

Figure 3:

Firm's objectives to use atypical employment (multiple selections) $^{3}$

\begin{tabular}{|c|c|}
\hline increased flexibility & $59,7 \%$ \\
\hline increased productivity & $23,2 \%$ \\
\hline $\begin{array}{r}\text { increased use of employee } \\
\text { capabilities }\end{array}$ & $\square 4,5 \%$ \\
\hline $\begin{array}{r}\text { enhancement of worker } \\
\text { satisfaction }\end{array}$ & $\square 3,9 \%$ \\
\hline enhancement of motivation & $\square 2,6 \%$ \\
\hline improvement of work climate & $1,3 \%$ \\
\hline $\begin{array}{r}\text { increased participation of } \\
\text { employees in planning and } \\
\text { production processes }\end{array}$ & ] $1 \%$ \\
\hline others & $\square 3,9 \%$ \\
\hline
\end{tabular}

$94 \%$ of the firms achieved their objectives, by and large. $2.5 \%$ denied such a goal achievement. Some firms $(3.5 \%)$ stated that they achieved the objectives only to some extent. They mentioned reasons such as low qualification and motivation of atypical employees as well as time-consuming break-ins. However, these statements are predominantly connected with temporary employment.

\section{Problems of utilisation}

Although the management of the firms very often stated that goals have been achieved by and large, it faces a set of problems. Figure 4 outlines the problems perceived by the management.

The management of the SMEs emphasises economic difficulties, such as problems with co-ordination, quality, and performance. The frequent change of atypical employees could also be interpreted as economic difficulty, as such change leads to costs of employing new personnel as well as expenses for break-in. The same results are found when the different forms of atypical employment are analysed separately.

The responses regarding actual problems with atypical employment made by the management of the firms are contrasted with responses from about 40 worker representatives (see figure 5).

Due to the limited number of questionnaires received by the worker representatives, responses could not be compared directly. However, two aspects should be raised here. 
Figure 4: temporary employment, part-time

Problems with atypical employment perceived by the management (multiple selections) ${ }^{4}$

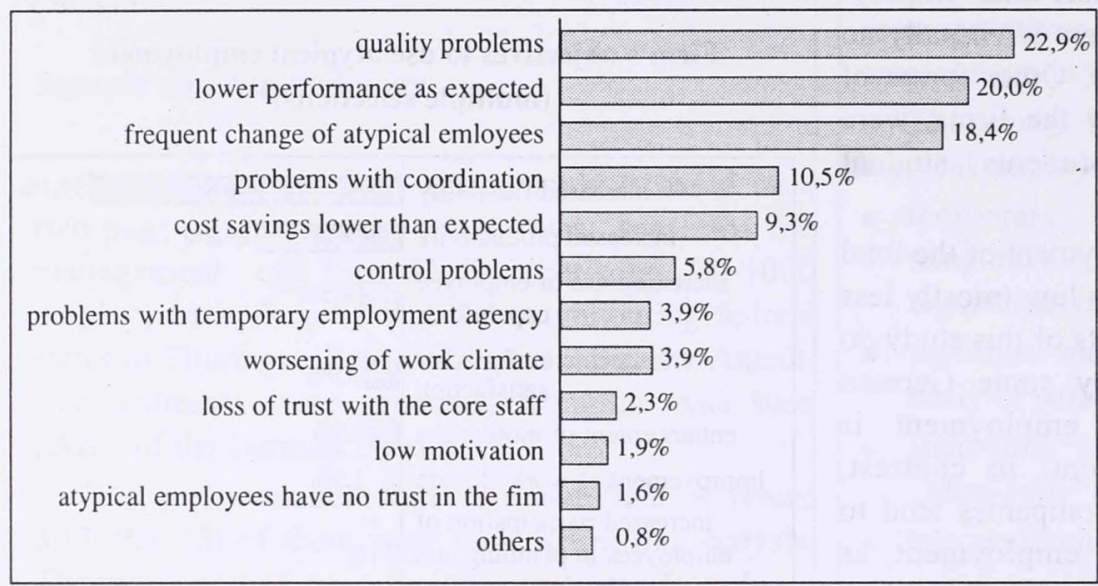

Responses of management and worker representatives regarding difficulties with atypical employment in the firms (multiple selections) 5

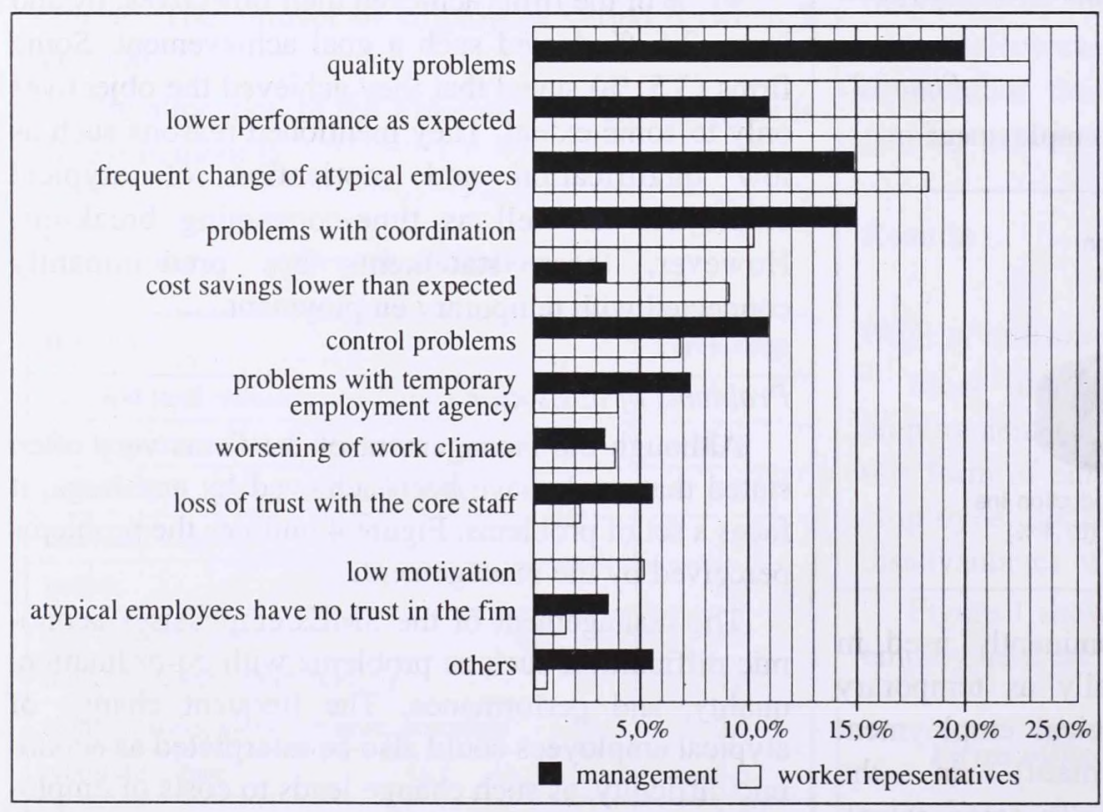
work, short-time employment. However, temporary employment is the dominant mode. The lower rate of part-time work and short-time employment among the SMEs could be a result of some particular German regulations on temporary employment. Temporary employment agencies have to guarantee the appropriate qualification of their employees. Thus, the firms are able to get the right employee for the right job, at least theoretically. If the employee is not suitable they have the right to replace him, like a faulty good. Consequently, temporary work has more advantages for the firms, as there are no costs for selection of personnel and break-in.

The very low usage of telecommuting found in this study stands in sharp contrast to the results of a recent study among firms in the area of Rhein-Main (West-Germany) made by Silvia Krömmelbein. She shows that medium-sized firms (50-499 employees) have the highest rates of telecommuting (Krömmelbein, 2002: 140.p.). On the one hand, the differences could be explained by the necessity of good computers and communication equipment as preconditioned for telecommuting. However, East-German firms usually do not have the financial re-sources to invest in information
Firstly, worker representatives emphasise not just economical difficulties. In particular, they stress social problems, such as worsening of the work climate or loss of trust. Secondly, worker representatives are more critical than the management. This is shown in the number of problems indicated, that is 2 (management) against 3 (worker representatives).

\section{Discussion}

The data show that East German SMEs use several modes of atypical employment, in particular and communication technology. On the other hand, the owners and CEOs of East-German SMEs have an orientation towards control and centralisation (Meinerz, 1996; Alt - Lang, 1997, 1998). However, with telecommuting, employees often work at home and therefore could not be monitored and controlled directly (Dimitrova, 2003: 191.p.; Topi, 2003: 81.p.).

The predominant utilisation of atypical employment in production lines indicates that this division could apparently be more easily split in different sub-processes and sub-tasks, which then are 
realised by different forms of atypical employment. Furthermore, the production line is the division of the companies where flexibility is realised. This, however, implicates that in production lines, a lack of trust between core staff and management could be expected. The job security of the core staff if permanently threatened when more flexibility is needed.

The goals of the company's management that conducts the use of atypical employment are predominantly of economic nature. This result, which is in line with the first research question, could be explained because of three reasons.

Firstly, it reflects response behaviour typical of the management. Against outsiders of the company, such as researchers, managers normally emphasise rational, economic and performance objectives. Moreover, such rational behaviour could also be internalised by the East-German CEOs, because they often are engineers. Alt - Lang (1998) and Lang - Müller (2001) found out that this particular background affects the behaviour of the East-German managers, which is described as rational and performance orientated.

Secondly, the low percentage of social objectives, such as to increase motivation and employee satisfaction, could be interpreted as specific orientation of the firm's management towards atypical employment. Such forms of employment are predominantly used by the management for economic reasons, whereas different instruments (e.g. flexible working hours) are perceived as useful for social objectives.

Thirdly, and in connection with these two aspects, the emphasis on economic objectives could indicate that the decision to use atypical employment is made by the management. Employee demands to reach a better work-live balance when working short-time or part-time is not a main reason for the utilisation of atypical employment in East-German small and medium sized business.

The management equally perceives economic problems such as frequent change of employees or reduced quality, associated with the company's usage of atypical employment. However, responses of the worker representatives also indicate social problems, such as worsening of work climate or loss of trust. The worker representatives normally are in direct contact with the core staff and atypical employees. Therefore, they perceive social problems on a higher level. Moreover, worker representatives emphasise more control and coordination problems compared to the management respondents. As the representatives are directly involved in the production process, they face difficulties, such as the need of vocational adjustment or the inadequate capabilities of atypical employees, on a daily basis. Therefore, they perceive such problems more often than the firm's management does. Furthermore, the worker representatives are more critical. On the one hand, this is due the more comprehensive experiences the worker representatives have on atypical employees in their everyday work. In contrast, it could be assumed that the management does not perceive all problems, because it is not involved in the day-to-day interaction processes on the work floor. On the other hand, the worker representatives' critical attitude towards atypical employment could be motivated by the fear that codetermination will disappear. Atypical employees are normally unaccounted for co-determination. Therefore, their rights are not represented by worker representatives.

\section{Conclusions}

Atypical modes of employment are established in East-German SMEs. The decision to introduce atypical employment is normally made by the firm's management, under economic considerations. Social purposes are less addressed. Although the management of the firms often stated that goals have been achieved by and large, it perceives a set of problems, in particular of economic nature. In contrast, the worker representatives also raise social problems. Moreover, they see the usage of atypical employment from a more critical point of view.

Looking at the amount as well as the manifoldness of the problems mentioned by the firm's management and the worker representatives, it becomes questionable whether the target advantages really are attained, as perceived by the management of most of the firms. Here, the perception of the management may have some bias based on two reasons.

Firstly, to dealing with the experienced difficulties needs time, investments in coordination and conflict management, as well as personnel efforts. However, these aspects often are neglected in economic considerations, as they are not detected by the company's cost accounting. Thus, there is no firm specific comparison of the advantages and 
disadvantages of atypical employment in economic terms, such as earnings and costs. The management considers earnings and costs savings, however neglects efforts to deal with difficulties.

Secondly, the firm's management is often not informed about all the problems of the company. To some extent, employees on the shop floor deal with difficulties that occur with atypical employment directly. As long as they can successfully deal with difficulties, they often do not report them to the management. Another explanation for the fact, that difficulties are not reported to the management, could be the fear of the employees of experiencing disadvantages or backlashes.

The present study only provides first insights to atypical employment in SMEs. Further research is needed in order to specify the causes of various problems. This could be a first step in order to develop strategies to cope with difficulties. Hereby, it could be assumed that certain difficulties are connected to different modes of atypical employment. Another future research direction in the field of atypical employment in SMEs is to analyse in detail, how the firms cope with the perceived difficulties. Interviews or direct observation in selected SMEs would allow for comprehensive insights into firm's processes. Thus, the more formal processes of coordination and control as well as the more informal social processes could be investigated. A particular research question would be how the different interest groups of a company are involved in problem solving.

\section{Literature}

Alt, R. - Lang, R. (1997): Führungskräfte in sächsischen Kleinund Mittelbetrieben, Forschungsbericht zum Projekt: „Wandel von Wertorientierungen und Organisationsauffassungen von Führungskräften in sächsischen Klein- und Mittelbetrieben. Eine Untersuchung unter dem Aspekt des wirtschaftlichen Wiederaufbaus", TU Chemnitz (Chemnitz)

Alt, R. - Lang, $R$. (1998): Wertorientierungen und Führungsverständnis von Managern in sächsischen Klein- und Mittelunternehmen, in: Lang, R. (Hrsg.), Führungskräfte im osteuropäischen Transformationsprozeß (Tagungsband des III. Chemnitzer Ostforums 1997), Rainer Hampp (München/Mering), S. 247-270.

Bellmann, L. - Dahms, V. - Wahse, J. (2004): IAB-Betriebspanel Ost: Ergebnisse der achten Welle 2003, Teil 2: Personalpolitik, Betriebliche Flexibilität, Weiterbildung, in: IAB-Forschungsbericht, Nr. 3/2004

Brewster, C. - Hegewisch, A. - Mayne, L. (1994): Flexible working practises. The controversy and the evidence, in: Brewster, C./Hegewisch, A. (eds.) Policy and practice in European human resource management, Routledge (London, New York), S. 168-193.
Brinkmann, U. (1996): Magere Bilanz: Neue Managementkonzepte (NMK) in transformierten ostdeutschen Betrieben, in: Pohlmann, M./Schmidt, R. (Hrsg.) Management in der ostdeutschen Industrie, Leske+Budrich (Opladen), S. 215-248.

Brinkmann, U. (2003): Die Labormaus des Westens: Ostdeutschland als Vorwegnahme des Neuen Produktionsmodells? in: Dörre, K./Röttger, B. (Hrsg.) Das neue Marktregime. Konturen eines nachfordistischen Produktionsmodells, VSA-Verlag (Hamburg), S. 250-269.

Cardon, M. S. (2003): Contingent Labour as an Enabler of Entrepreneurial Growth, in: Human Resource Management, 42/4, S. 357-373.

Corral, A. - Isusi, I. (2003): Part-time work in Europe, European Foundation for the Improvement of Living and Working Conditions, Dublin

Dimitrova, D. (2003): Controlling teleworkers: supervision and flexibility revisited, in: New Technology, Work and Employment, 18/3, S. 181-195.

Düll, H. - Ellguth, P. (1999): Betriebliche Strukturen der Teilzeitbeschäftigung in West- und Ostdeutschland, in: MittAB, 3/99, S. 269-280.

Foote, D.A. - Folta, T.B. (2002): Temporary workers as real options, in: Human resource Management Review, Vol. 11, S. 181-208.

Grimm, N. (2004): Flexibilität durch Leiharbeit: Zumutung oder Chance? in: SOFI-Mitteilungen, 32, S. 129-139.

Hoffmann, E.-.Walwei, U. (1998): Normalarbeitsverhältnis: ein Auslaufmodell?, in: MittAB, 3/1998, S. 409-425.

IAB-Betriebspanel Ost (2003): Ergebnisse der siebten Welle 2002, SÖSTRA Sozialökonomische Strukturanalyse GmbH Berlin

Krömmelbein, S. (2000): Bedeutung der Telearbeit für Beschäftigung und Arbeitsmarkt am Beispiel der Region Rhein-Main aus betrieblicher Sicht, in MittAB, 1/2000, S. 136-...

Lang, R. - Müller, S. (2001): Privatisation, Perception of Success and Attitudes of Managers in the East German Transformation Process, in: Liuhto, K. (Ed.): Ten Years of Economic Transformation. Volume III: Societies and Institutions in Transition. Studies in Industrial Engineering an Management Number 16. Lappeenranta University of Technology, S. 391-407.

Martin, A. - Nienhüser, W. (2002): Neue Formen der Beschäftigung, in: Martin, A./Nienhüser, W. (Hrsg.) Neue Formen der Beschäftigung - neue Personalpolitik?, Sonderband der ZfP, Rainer Hampp Verlag/München und Mering, S. 1-16.

Matusik, S. - Hill, C. (1998): The utilization of contingent work, knowledge creation, and competitive advantage, in: Academy of Management Review, Vol. 23, S. 608-697.

Mayne, L. - Tregaskis, O. - Brewster, C. (2000): A Comparative Analysis of the Link Between Flexibility and HRM Strategy, in: Brewster, C./Mayrhofer, W./Morley, M. (Hrsg.) New Challenges for European Human Resource Management, MacMillan (London), 72-96.

Meinerz, K.P. (1996): Einstellungen, Werthaltungen und Leitbilder von Managern in Ostdeutschland. Kognitive und normative Voraussetzungen der Rekonstruktion betrieblicher Sozialbeziehungen, in: Pohlmann, M./Schmidt, R. (Hrsg.), Management in der ostdeutschen Industrie, Leske + Budrich (Opladen), S. 177216.

Nienhüser, W. - Baumhus, W. (2002): Fremd im Betrieb, in: Martin, A./Nienhüser, W. (Hrsg.) Neue Formen der Beschäftigung - neue Personalpolitik?, Sonderband der ZfP, Rainer Hampp Verlag/München und Mering, S. 61-120.

Pearce, J.L. (1993): Toward an organizational behavior of contract laborers: Their psychological involvement and effects on employee co-workers, in: AMJ, 36/5, S. 1082-1096. 
Rudolph, H. - Schröder, E. (1997): Arbeitnehmerüberlassung: Trends und Einsatzlogik, in: MittAB, 1/1997, S. 102-126.

Schäfer, H. (2000): Atypische Beschäftigung, Entwicklungstrends und Bedeutung für den Arbeitsmarkt, in: iw-trends, 27/4, S. 4154.

Topi, H. (2004): SUPPORTING TELEWORK: OBSTACLES AND SOLUTIONS, in: Information Systems Management, 21/3, S. 79-86.

Vogel, B. (1999): Arbeitslosigkeit in Ostdeutschland. Konsequenzen für das Sozialgefüge und für die Wahrnehmung des gesellschaftlichen Wandels, in: SOFI-Mitteilungen, 27, S. 15-23

Without Author (1998): Mitbestimmung und neue Unternehmenskulturen. Bilanz und Perspektiven, Herausgegeben von der Bertelsmann Stiftung und der Hans-Böckler-Stiftung, Verlag Bertelsmann Stiftung (Gütersloh)

\section{Endnotes}

1 All in all, the German discussion on atypical employment emphasises aspects of cost savings and flexibility raise. Different aims, such as to keep excellent employees in order to provide them opportunities for an individual work-live-balance (Tilly, 1992), or contingent workers as resource to acquire new knowledge (Matusik - Hill, 1998; Foote - Folta, 2002), could be nearly exclusive found in the international discussion.

2 The question, whether this indicates a strategic utilisation of atypical employment, a point raised by Mayne et al. (2000: 72.p.), could not be answered from the available data.

3 The category ,others" comprises statements such as, search for qualified employees by temporary work, search for new knowledge, and prevention of familial problems.

4 The two entries in the category ,other" are: „long access routes" and ,problems with workers council”.

5 In the category „other" the worker representatives made the statements "frequent break-ins burden core staff" and „vocational adjustment is needed in order to get the desired performance". 